\title{
BULLA PAPIEŻA BONIFACEGO IX ERYGUJĄCA WYDZIAE TEOLOGICZNY NA UNIWERSYTECIE KRAKOWSKIM
}

BONIFACY biskup, sługa sług Bożych. Na wieczną rzeczy pamiątkęt. NIEZWYKŁEGO PRZYWIĄZANIA UCZUCIE, jakie najdroższy w Chrystusie syn nasz Władysław król i najdroższa w Chrystusie córka nasza Jadwiga, królowa Polski, najjaśniejsi, okazują nam i Kościołowi Rzymskiemu, zasługuje na to, abyśmy się przychylnie odnieśli do ich życzeń, a zwłaszcza do tych, przez które rozszerza się cześć imienia Bożego i wiary katolickiej, utrzymuje się sprawiedliwość, z korzyścią toczą siẹ sprawy państwowe i prywatne, pomnaża się wszelka ludzka pomyślność.

Ponieważ więc - jak podawała przedstawiona nam niedawno przez wymienionych króla i królowę prośba - w ich mieście Krakowie, na mocy rozporządzenia Stolicy Apostolskiej, od dawna było i jest studium powszechne obejmujące wydziały obojga praw i inne, z wyjątkiem teologii, a ze strony wspomnianych króla i królowej proszono nas, abyśmy w wyżej wymienionym mieście raczyli z łaski apostolskiej ustanowić i założyć wydział teologiczny na tymże studium - przeto do tych próśb się skłaniając, powagą apostolską niniejszym pismem postanawiamy i za.rządzamy, ażeby w tymże mieście odtąd w przyszłości po wieczne czasy był i mógł być wydział teologiczny, na czele którego ma stać ten, co i dotąd od dawna stał na czele.

Niemniej, jako wyraz szczególnej łaski, pozwalamy, ażeby studenci i kierujący, jacy w danym czasie będą na teologii, oraz ci, którzy uzyskają stopnie bakałarza, licencjata i doktora, cieszyli się i korzystali z wszystkich przywilejów i uprawnień, z jakich korzystają studenci i kierownicy oraz zdobywający podobne stopnie w Paryżu.

Żadnemu człowiekowi nie wolno tej karty naszego rozporządzenia, postanowienia i nadania złamać, albo z zuchwałym uporem jej się sprzeciwiać. Gdyby zaś ktoś się na to odważył, niech wie, że działa przeciwko Wszechmocnemu Bogu i świętym Jego Apostołom Piotrowi i Pawłowi.

Dan w Rzymie, u świętego Piotra, dnia 11 stycznia roku ósmego naszego pontyfikatu [11 I 1397]. 